\title{
Using tilapia skin (Oreochromis niloticus) as an occlusive biological curative in equine wounds: short communication
}

\author{
Uso da pele de tilápia (Oreochromis niloticus) como curativo biológico \\ oclusivo em feridas de equinos: nota prévia
}

\author{
Sofia Cicolo da Silva ${ }^{1}$; ; Vívian Fratti Penna Ríspoli²; Cesar Graner³; Lilian Rose Marques de Sá2; \\ Carla Bargi Belli; André Luís do Valle De Zoppa ${ }^{1}$
}

\begin{abstract}
${ }^{1}$ Universidade de São Paulo, Faculdade de Medicina Veterinária e Zootecnia, Departamento de Cirurgia Veterinária, São Paulo - SP, Brazil
${ }^{2}$ Universidade de São Paulo, Faculdade de Medicina Veterinária e Zootecnia, Departamento de Patologia, São Paulo - SP, Brazil

${ }^{3}$ Universidade de São Paulo, Faculdade de Medicina Veterinária e Zootecnia, Departamento de Clínica Médica, São Paulo - SP, Brazil
\end{abstract}

\begin{abstract}
Tilapia skin is being already use in humans and wild animals present burning wounds and showed a great result. The objective is to evaluate if tilapia skin used as an occlusive curative improves equine wound healing in two horses present chronic wound. Both animals are males, adults, both of breed Mangalarga Marchador South America. Every seven days wound we measured, photographed, biopsied for histopathological analysis, cleaned and tilapia curative was changed. Image J software was used to measure wound area. Tilapia skin as an occlusive biological factor seemed to improve healing process, wounds present an area reduction and clinical improvement during 35 days treatment, even though is still waiting for complete wound healing. In equine tilapia skin curative seemed to speed up healing process and allowed reduced curative change from every two days to once a week. This implies in decrease animal's stress, less pain and treatment cost reduction since we used less bandage amount. Beside that tilapia skin industrial waste. Furthermore, it allowed avoid using antibiotics, which reduces environment pollution and there's no antibiotic resistance issues.
\end{abstract}

Keywords: Horse. Graft. Skin regeneration. Fish skin.

\section{RESUMO}

A pele de tilápia está sendo utilizada em humanos e animais silvestres com feridas por queimadura demonstrando um excelente resultado. O objetivo do estudo é avaliar se a pele de tilápia utilizada como curativo oclusivo melhora o processo de cicatrização em dois equinos machos adultos da raça Mangalarga Machador, os quais apresentam feridas crônicas. A cada 7 dias as feridas eram medidas, fotografadas, biopsiadas para a análise histopatológica, limpas e o curativo de pele de tilápia trocado. O programa Image J foi utilizado para calcular a área da ferida. A pele de tilápia utilizada como curativo oclusivo parece ter um efeito positivo na cicatrização das feridas, a área diminuiu e a o aspecto clínico melhorou nos 35 dias avaliados, no entanto é necessário esperar pela cicatrização completa das feridas. Em equinos, a utilização de curativo de pele de tilápia parece diminuir o tempo de cicatrização e permite a redução do número de trocas de curativos de a cada dois dias para uma vez por semana. Isso implica em menos estresse e dor para o animal devido à menor manipulação e menor custo de tratamento, pois há menor quantidade de material de curativo sendo utilizado. Além disso, permite evitar a utilização de antibióticos, o que diminui o impacto ambiental e não gera resistência.

Palavras-chave: Cavalos. Enxerto. Regeneração cutânea. Pele de peixe.

Correspondence to:

Sofia Cicolo da Silva

Universidade de São Paulo, Faculdade de Medicina Veterinária

e Zootecnia, Departamento de Cirurgia Veterinária

Av. Prof. Dr. Orlando Marques de Paiva, 87

CEP: 05508-270, São Paulo - SP, Brazil

e-mail: sofiacicolo@gmail.com

Received: January 29, 2019

Approved: June 03, 2019
How to cite: Silva SC, Ríspoli VFP, Graner C, Sá LRM, Belli CB, Zoppa ALV. Using tilapia skin (Oreochromis niloticus) as an occlusive biological curative in equine wounds. Short communication. Braz J Vet Res Anim Sci. 2019;56(4):e154079. https://doi.org/10.11606/issn.1678-4456.bjvras.2019.154079

Horses frequently suffer traumatic wounds. They can become chronic wound, presenting delay and complication to heal especially in distal extremities. A considerable number 
of animals have their athletic career jeopardized because of persisting lameness, swollen limbs, exuberant granulation tissue and extensive scars. Although primary or delayed closure is preferred as treatment it's not always possible, in cases of unmanageable contamination, excessive tissue loss or severe compromise of the tissue, wound healing by second intention is often the only option (Caron, 1999; Hendrickson \& Virgin, 2005; Wilmink \& Van Weeren, 2005).

The local environment exerts have an important impact on wound repair. Exuberant granulation tissue (EGT) appears to be influenced by inflammatory mediators. In equine dermal healing a weak persistent inflammatory response occurs, which is more pronounced in the extremities than in the trunk. EGT develops more in limb wounds and spare body wounds. Occlusion of the microvasculature suggests that the presence of relative tissue hypoxia is detrimental to the inflammatory response and encourages excessive angiogenesis and fibroproliferation via cytokines and other mediators (Theoret et al., 2013).

Neutrophils and macrophages infiltrate the wound and are thought to help clear the wound and produce cytokines (Mirza et al., 2009). Leukocytes in ponies produce more reactive oxygen species (ROS) than horses, which is necessary for bacterial killing. The low initial production of TNFa, IL-1, chemoattractants, TGF- $\beta$, and ROS in horses can explain the weak onset of the inflammatory response and the ensuing persistence of inflammation (Wilmink \& Van Weeren, 2005).

Recently, fish collagen has gradually attracted attention because of its abundance and low price. Tilapia skin collagen sponge and electrospun nanofibers were developed for wound dressing. It was composed of at least two a-peptides. They had good thermal stability and swelling properties and could significantly promote the proliferation of human keratinocytes and stimulate epidermal differentiation through the up-regulated gene expression of involucrin, filaggrin, and type I transglutaminase in human keratinocytes. The collagen nanofibers could also facilitate rat skin regeneration (Zhou et al., 2016). It also showed a good result in burn wounds in humans (Lima-Júnior, 2017).

Amino Acid Composition (MCPs) from fish differs greatly from those from terrestrial livestock in physicochemical properties, they also present unique physiological functions including antibacterial, antioxidant, antihypertensive, neuroprotective and anti-skin-aging activities. MCPs from the skin of tilapia contained seven essential amino acids and ten nonessential amino acids. Collagen hydrolysates usually contain a high concentration of collagen tripeptides (Hu et al., 2017).

Fresh tilapia skin was donated by a fisher farm. The samples were emerged in aqueous chlorhexidine $0.2 \%$ for 20 minutes, wrapped in gauze and then frozen. To prepare the tilapia skin for use, the samples were rehydrated using sterile saline solution.

The present study is the first reporting using tilapia skin as a wound dressing, it was applied in two horses that presented chronic wounds. Animals are sedated using xylazine $10 \%$ and diagnostic biopsy (6 $\mathrm{mm}$ diameter) was collected every 7 days, wounds were measured and area calculated by Image J software (Table 1). Results showed habronemiasis and EGT on the first animal biopsy and EGT and eosinophilic dermatitis on the second patient. Animal 2 presented wounds only in limbs and the second one had wounds on both pelvic limbs and back. EGT on animal 1 was resected with a scalpel blade and oral ivermectin was administered. All wounds were cleaned with sterile saline solution containing gentamicin $(1.6 \mathrm{~g} / \mathrm{L})$ and gauze. Tilapia skin was applied in both cases covering the whole area of the wound. The following procedure involved the bandage of the wound with orthopedic cotton and vet wrap. Diaper and tape were used on the recovery to keep the moisture of the tilapia skin for the next 7 days.

After 3 days, the bandage from animal 2 left limb was changed, because he has bitten it. After seven days, the wounds from animal number 2 were healthy pink, there was a fibrin layer recovering and EGT had disappeared. There was a considerable reduction in wound size. The same bandage changing protocol proceeded, repeated using saline solution only. Animal 1 did not show the same progress due to the lack of contact between the horse's skin and the tilapia skin created by blood as the result of the EGT resection.

Presence of fur in the healing region near the edges was noticed after 14 days of evolution. The middle of the wound was healthy pink and a great large area of the edges of the wound was epithelialized in both cases. The same

Table 1 - Wound area $\mathrm{cm}^{2}$ during tilapia skin treatment; Area Before (before treatment); Area 35 days (After 35 days changing tilapia skin once a week); Percentage wound reduction (wound area before treatment/wound area after 35 days)

\begin{tabular}{lccccc}
\hline & Wound 1 A & Wound 1 B & Wound 2 A & Wound 2 B & Wound 2 C \\
\hline Area Before $\left(\mathrm{cm}^{2}\right)$ & 25 & 31.8 & 110.47 & 6.29 & 12.164 \\
Area 35 Days $\left(\mathrm{cm}^{2}\right)$ & 4 & 19 & 53 & 2.8 & 10.4 \\
Percentage wound reduction \% & 84 & 40.3 & 52.1 & 55.5 & 14.6 \\
\hline
\end{tabular}

Area of wound before applying tilapia skin and after 35 days. 
bandage changing protocol from day 7 was repeated. A great reduction in wound size, on Table 1, along with surface epithelization was noticed after 28 days of treatment, as shown in Figure 1 to 3.
Our findings indicate that tilapia skin seemed to improve wound healing in chronic wounds and it decreases EGT formation with no collateral effects, even though a complete histopathological analysis is still needed as well as waiting for

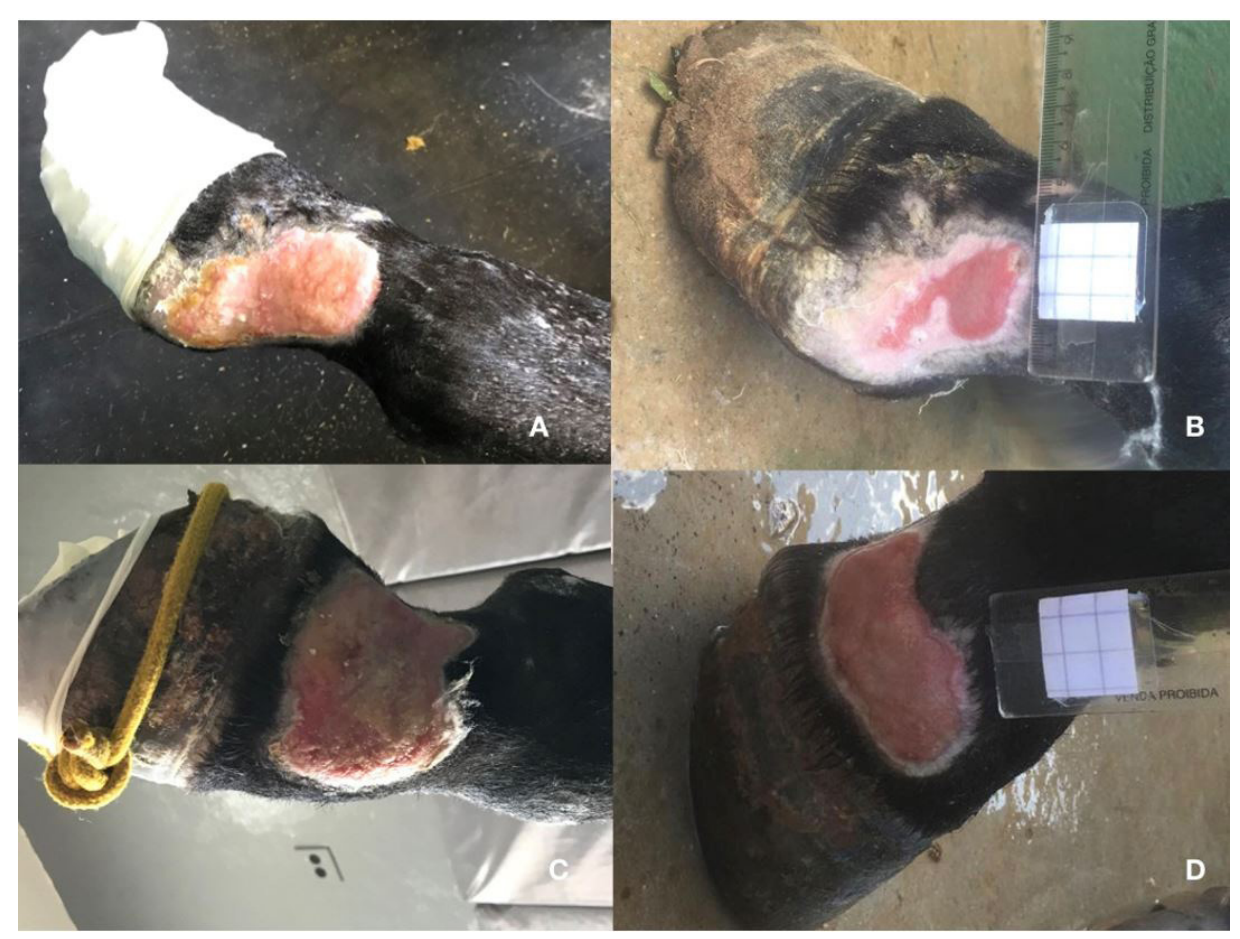

Figure 1 -(A) Animal 1 front limb wound before applying tilapia skin; (B) Animal 1 front limb wound after 42 days using tilapia skin bandage; (C) Animal 1 pelvic limb wound before applying tilapia skin; (D) Animal 1 pelvic limb wound after 42 days using tilapia skin bandage.

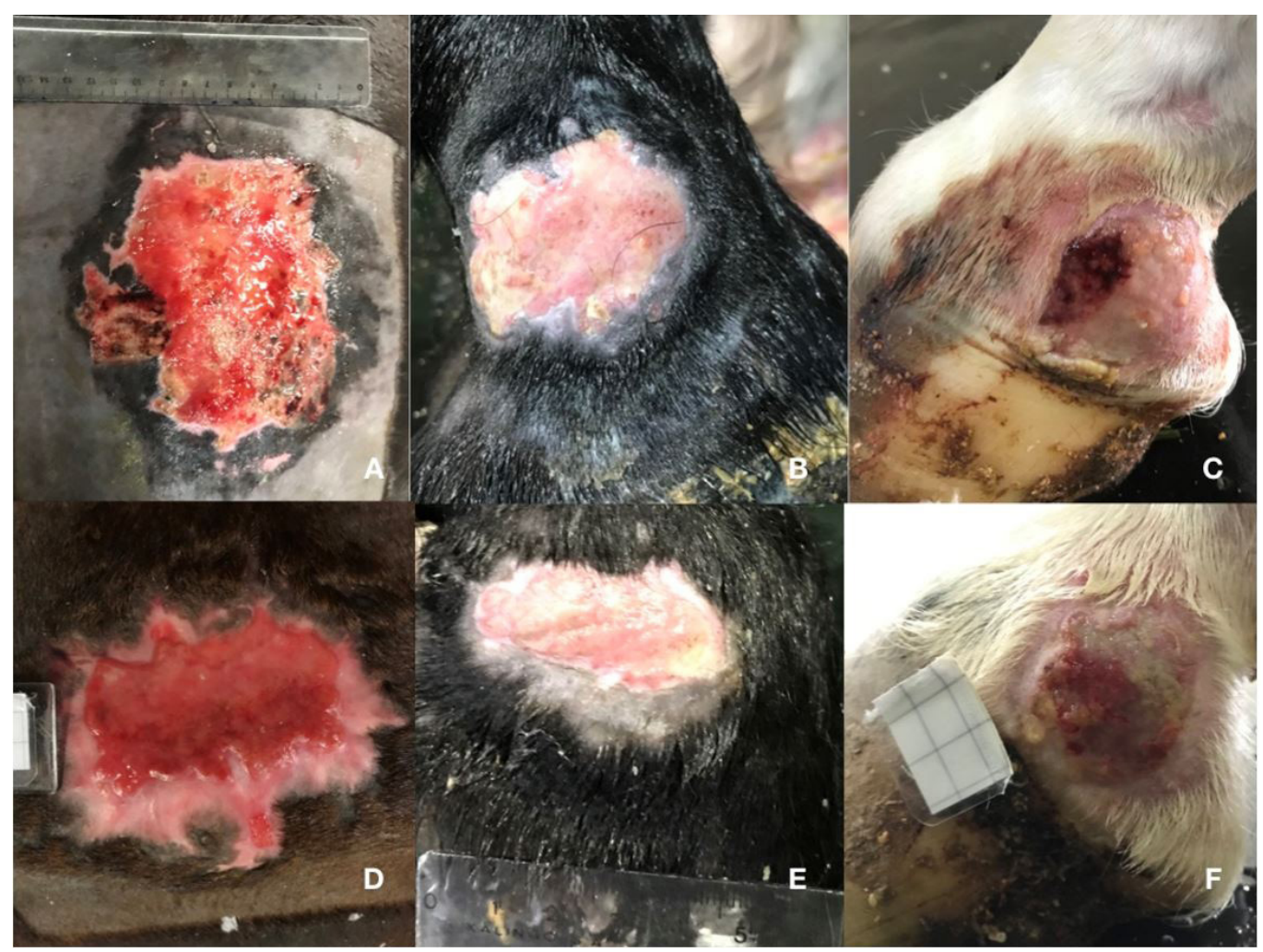

Figure 2 -(A) Animal 2 back wound before applying tilapia skin; (B) Animal 2 back wound after 35 days using tilapia skin bandage; (C) Animal 2 right pelvic limb wound before applying tilapia skin; (D) Animal 2 right pelvic limb wound after 35 days using tilapia skin bandage; (E) Animal 2 left pelvic limb wound before applying tilapia skin; (F) Animal 2 left pelvic limb wound after 35 days using tilapia skin bandage. 


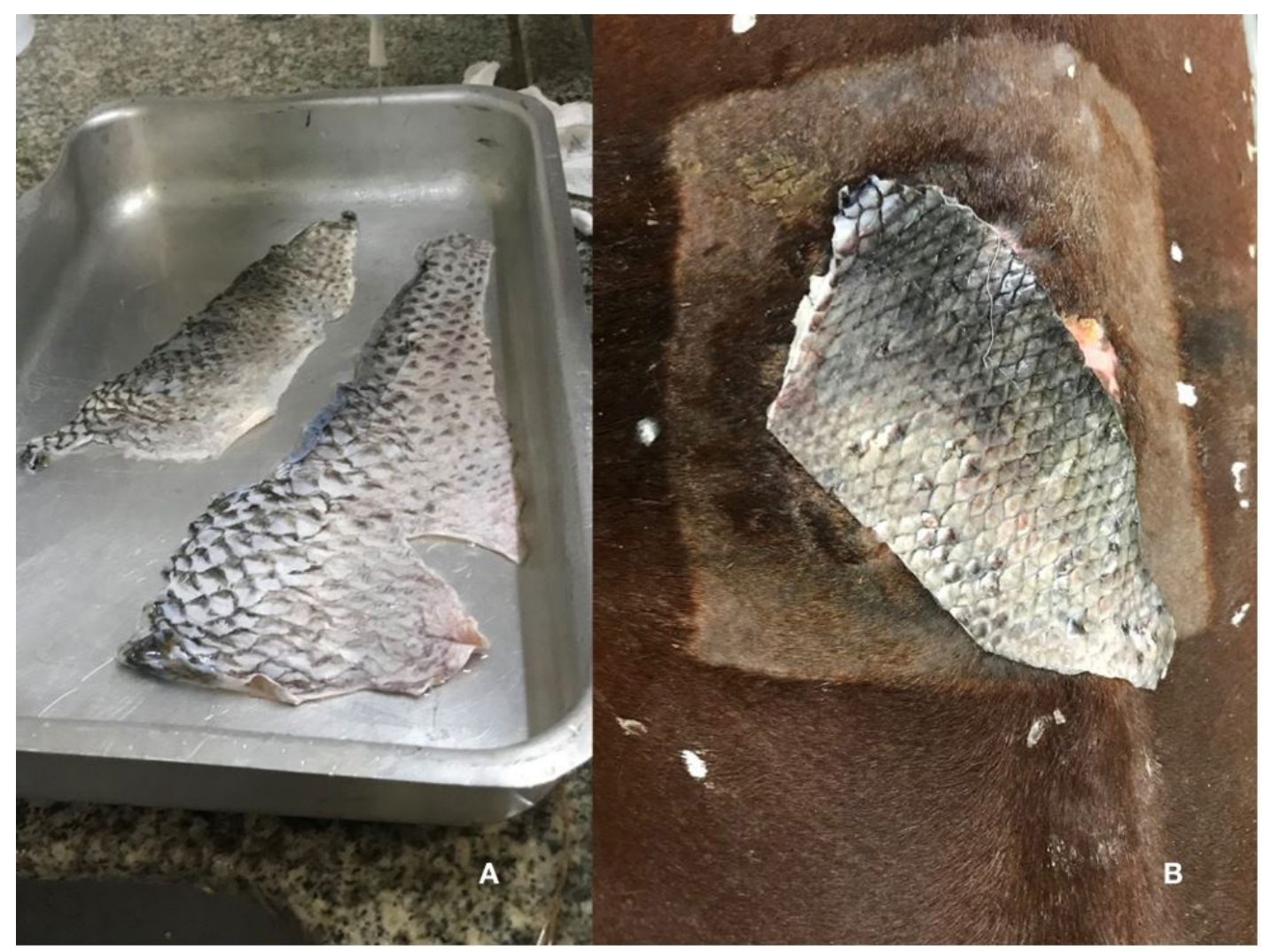

Figure 3 - (A) Preparing frozen tilapia skin to apply; (B) Tilapia sking applied in animal's 1 back wound.

complete wound healing. No ATB were administered during treatment. Furthermore, in our routine, wound bandages are usually changed every 2 days, so a lot of material was spared, since we changed it every 7 days.

\section{Conflict of Interest}

None of the authors of this paper has a financial or personal relationship with other people or organizations that could inappropriately influence or bias the content of the paper.

\section{References}

Caron JP. Management of superficial wounds. In: Auer JA, Stick JA, editors. Equine surgery. Philadelphia: W. B. Saunders; 1999. p. 129-40. (vol. 1).

Hendrickson D, Virgin J. Factors that affect equine wound repair. Vet Clin North Am Equine Pract. 2005;21(1):33-44. http://dx.doi.org/10.1016/j.cveq.2004.11.002. PMid:15691598.

Hu Z, Yang P, Zhou C, Li S, Hong P. Marine collagen peptides from the skin of Nile Tilapia (Oreochromis niloticus): characterization and wound healing evaluation. Mar Drugs. 2017;15(4):102. http://dx.doi.org/10.3390/md15040102. PMid:28358307.

\section{Ethics Statement}

This research project was approved by the Animal Use Ethics Committee of FMVZ-USP under the number CEUA No3731111218.

\section{Acknowledgements}

Valdir and Gabriela Sibaldo Diniz for tilapia skin donation. Marina Civita for review of English.

Lima-Júnior EM. Uso da pele de tilápia (Oreochromis niloticus), como curativo biológico oclusivo, no tratamento de queimaduras. Rev Bras Queimaduras. 2017;16(1):7-10.

Mirza R, Dipietro LA, Koh TJ. Selective and specific macrophage ablation is detrimental to wound healing in mice. Am J Pathol. 2009;175(6):2454-62. http://dx.doi. org/10.2353/ajpath.2009.090248. PMid:19850888.

Theoret CL, Olutoye OO, Parnell LK, Hicks J. Equine exuberant granulation tissue and human keloids: a comparative histopathologic study. Vet Surg. 2013;42(7):783-9. http://dx.doi. org/10.1111/j.1532-950X.2013.12055.x. PMid:24015864. 
Wilmink JM, Van Weeren PR. Second-intention repair in the horse and pony and management of exuberant granulation tissue. Vet Clin North Am Equine Pract. 2005;21(1):15-32. http://dx.doi.org/10.1016/j.cveq.2004.11.014. PMid:15691597.

Zhou T, Wang N, Xue Y, Ding T, Liu X, Mo X, Sun J. Electrospun tilapia collagen nanofibers accelerating wound healing via inducing keratinocytes proliferation and differentiation. Colloids Surf B Biointerfaces. 2016;143:415-22. http:// dx.doi.org/10.1016/j.colsurfb.2016.03.052. PMid:27037778.
Financial Support: Scholarship FAPESP 2019/04850-5.

Authors Contributions: Cesar Graner and Vívian Fratti Penna Ríspoli helped during bandage changing and tilapia's skin preparing for use. Sofia Cicolo da Silva, Vívian Fratti Penna Ríspoli, Lilian Rose Marques de Sá, André Luís do Valle De Zoppa and Carla Bargi Belli helped article writing process and during bandaging changing process. Sofia Cicolo da Silva idealized the project. 